\title{
PENGARUH PERSEPSI PASIEN UMUM KELAS III TENTANG KUALITAS PELAYANAN TERHADAP CITRA RUMAH SAKIT DI INSTALASI RAWAT INAP RS IBNU SINA YBW-UMI MAKASSARTAHUN 2019
}

\author{
Sherly Rudianti Batter ${ }^{1}$, Anwar ${ }^{2}$, Muhammad Khidri Alwi ${ }^{3}$ \\ ${ }^{1}$ Pascasarjana Universitas Muslim Indonesia \\ ${ }^{2}$ Pascasarjana Universitas Muslim Indonesia \\ ${ }^{3}$ Pascasarjana Universitas Muslim Indonesia
}

Alamat korespondensi: (sherlyrudianti@yahoo.co.id/085256764844)

\begin{abstract}
ABSTRAK
Citra terbentuk dari bagimana perusahaan melaksanakan kegiatan operasionalnya yang mempunyai landasan utama pada segi pelayanan. Penelitian ini bertujuan untuk mengetahui bagimana persepsi pasien tentang kualitas pelayanan terhadap citra Rumah Sakit Ibnu Sina. Jenis penelitian ini adalah penelitian kuantitatif dengan pendekatan cross sectional study. Populasi dalam penelitian ini adalah seluruh pasien kelas III yang berada ruang rawat inap RS Ibnu Sina. Besar sampel dalam penelitian ini sebanayak 72 responden dengan perhitungan jumlah sampel dengan menggunakan taraf kesalahan 5\%. Data dianalisis menggunakan uji chi squar dan binary logistic. Hasil penelitian menunjukkan bahwa persepsi pasien umum tentang kualitas pelayanan terhadap citra RS. Ibnu Sina Makassar ditinjau dari dimensi penampilan fisik tidak memiliki hubungan yang signifikan dengan nila $p=1,000>\alpha(0,05)$. Sedangkan persepsi pasien umum tentang kualitas pelayanan terhadap citra RS. Ibnu Sina Makassar ditinjau dari dimensi kompeten dan kepercayaan, memiliki hubungan yang signifikan dengan nilai $p=0,000<\alpha(0,05)$. Kesimpulan dalam penelitian tidak ada hubungan penampilan fisik terhadap citra RS. Ibnu Sina Makassar dan ada hubungan kompeten dan kepercayaan terhadap citra RS. Ibnu Sina Makassar tahun 2019. Diharapkan kepada instansi terkait, pembenahan kualitas pelayanan dari dimensi untuk peningkatan citra rumah sakit harus dari prioritas perbaikan dimensi yang memiliki pengaruh yang kuat dalam peningkatan citra rumah sakit.
\end{abstract}

Kata Kunci: Kualitas Pelayanan, Citra Rumah Sakit, Kepercayaan Pasien

\section{PENDAHULUAN}

Berdasarkan data tahun 2005, sekitar 40 persen jumlah pasien internasional atau dari luar Singapura di Tan Tock Seng Hospital (TTSH) dan National University Hospital (NUH) berasal dari Indonesia. Jumlah itu meningkat delapan persen dibanding tahun 2004. Di NUH, tahun 2005 tercatat sekitar 49.000 pasien internasional, dan 44\% merupakan pasien Indonesia. NUH dan TTSH merupakan rumah sakit milik pemerintah Singapura. Bulan April 2018 lalu salah satu stasiun TV swasta menayangkan bahwa tahun 2016 pasien dari Indonesia yang berobat di rumah sakit Singapura sebanyak 30\% dan pada tahun 2017 meningkat lagi menjadi 50\% (WHO, 2017).

Berdasarkan data yang diperoleh dari RS Ibnu Sina, jumlah kunjungan pasien umum rawat inap untuk kategori kelas III perawatan, mengalami trend penurunanan setiap tahunnya terhitung sejak tahun 2015 sebanyak 10.558 pasien, tahun 2016 sebanyak 12.438 pasien tahun 2017 sebanyak 9.478 pasien dan data jumlah pasien yang rawat inap pada periode Januari - September tahun 2018 sebanyak 7.588 pasien (Rekam Medik RS. Ibnu Sina Kota Makassar, 2018).

Penurunan tersebut memperlihatkan bahwa kemungkinan terjadi gap antara harapan yang diinginkan pasien dengan perlakuan yang diterima pada saat memanfaatkan pelayanan kesehatan, sehingga mempengaruhi penilaian pasien terhadap kualitas pelayanan di Rumah Sakit Ibnu Sina YBW-UMI Makassar. Pelayanan yang tidak berjalan baik dapat menyebabkan kurangnya minat pasien untuk memanfaatkan pelayanan kesehatan di RS Ibnu Sina.

Berdasarkan latar belakang yang telah diuraikan tersebut maka peneliti bermaksud untuk melakukan penelitian dengan judul "Bagaimana Pengaruh Persepsi Pasien Umum Kelas III Tentang Kualitas Pelayanan Terhadap Citra Rumah Sakit Di Instalasi Rawat Inap Rumah Sakit Ibnu Sina YBW-UMI Makassar 2019. 
Analisis Data

1. Analisis Univariat

Merupakan analisis yang dilakukan terhadap tiap variabel dari hasil penelitian.Dimana pada umumnya, menghasilkan distribusi dan prosentase dari tiap variabel (Notoatmodjo, 2005:188).

2. Analisis Bivariat

Analisis bivariat yaitu analisis terhadap variabel yang diduga berhubungan atau berkorelasi (Notoatmodjo, 2005:188). Uji statistik yang digunakan adalah chi square dengan taraf signifikan yang digunakan adalah 95\% dengan nilai kemaknaan 0,05.

\section{HASIL PENELITIAN}

1. Analisis Univariat

Tabel 1. Karakteristik Responden Berdasarkan Umur, Jenis Kelamin, Pendidikan, dan Pekerjaan Di RS. Ibnu Sina Makassar $(\mathrm{n}=72)$

\begin{tabular}{|c|c|c|}
\hline \multicolumn{3}{|l|}{ Karakteristik } \\
\hline \multicolumn{3}{|l|}{ a. Umur } \\
\hline$\geq 20$ thn & 13 & 18,1 \\
\hline $21-40$ thn & 36 & 48,6 \\
\hline $40-60$ thn & 24 & 33,3 \\
\hline \multicolumn{3}{|l|}{ b. Jenis Kelamin } \\
\hline Laki-laki & 24 & 33,3 \\
\hline \multicolumn{3}{|l|}{ c. Pendidikan } \\
\hline SD & 16 & 22,2 \\
\hline SMP & 10 & 13,9 \\
\hline SMA & 28 & 38,9 \\
\hline \multicolumn{3}{|l|}{ d. Pekerjaan } \\
\hline Siswa/Mahasiswa & 11 & 15,3 \\
\hline IRT & 17 & 23,6 \\
\hline Buruh Harian & 14 & 19,4 \\
\hline Wiraswasta & 20 & 27,8 \\
\hline Pegawai BUMN & 2 & 2,8 \\
\hline PNS & 6 & 8,3 \\
\hline
\end{tabular}

Tabel 1 di atas menunjukkan bahwa dari 72 responden yang dijadikan sampel, karakteristik berdasarkan umur yang paling banyak pada rentang usia 21-40 thn yakni sebanyak 36 responden $(48,6 \%)$, dan yang paling sedikit pada usia $>20$ thn 13 responden (18,1). Berdasarkan Jenis kelamin yang paling banyak pada laki-laki yakni sebanyak 48 responden $(66,7 \%)$ dan yang paling sedikit pada perempuan yakni 24 responden (33,3\%). Berdasarkan Pendidikan yang paling banyak pada pendidikan SMA yakni 28 responden $(38,9 \%)$ dan paling sedikit pada pendidikan SMP yakni 10 responden (13,9\%). Berdasarkan Pekerjaan yang paling banyak pada wiraswasta yakni 20 responden $(27,8 \%)$ dan yang paling sedikit pada pegawai BUMN yakni 2 responden $(2,8 \%)$.
Tabel 2. Distribusi Persepsi Pasien Umum Kelas III Berdasarkan Penampilan Fisik Di RS. Ibnu Sina Makassar. $(n=72)$

\begin{tabular}{|c|c|c|}
\hline Bukti Fisik & $\mathrm{n}$ & $\%$ \\
\hline Kurang & 2 & 2,8 \\
\hline Cukup & 70 & 97,2 \\
\hline Total & 72 & 100 \\
\hline
\end{tabular}

Tabel 2 di atas menunjukkan bahwa dari 72 responden yang dijadikan sampel, terdapat 2 responden $(2,8 \%)$ yang memiliki persepsi tentang kualitas pelayanan dari dimensi penampilan fisik masih kurang dan terdapat 70 responden $(97,2 \%)$ yang memiliki persepsi tentang kualitas pelayanan dari dimensi penampilan fisik cukup.

Tabel 3. Distribusi Persepsi Pasien Umum Kelas III Berdasarkan Kompeten Di RS. Ibnu Sina Makassar. $(\mathrm{n}=72)$

\begin{tabular}{|c|c|c|}
\hline Kompeten & $\mathrm{n}$ & $\%$ \\
\hline Kurang & 5 & 6,9 \\
\hline Cukup & 67 & 93,1 \\
\hline Total & 72 & 100 \\
\hline
\end{tabular}

Tabel 3 di atas menunjukkan bahwa dari 72 responden yang dijadikan sampel, terdapat 5 responden $(6,9 \%)$ yang memiliki persepsi tentang kualitas pelayanan dari dimensi kompeten kurang dan terdapat 67 responden $(93,1 \%)$ yang memiliki persepsi tentang kualitas pelayanan dari dimensi kompeten cukup.

Tabel 4. Distribusi Persepsi Pasien Umum Kelas III Berdasarkan Kepercayaan Di RS. Ibnu Sina Makassar. $(n=72)$

\begin{tabular}{|c|c|c|}
\hline Kepercayaan & $\mathrm{n}$ & $\%$ \\
\hline Kurang & 4 & 5,6 \\
\hline Cukup & 68 & 94,4 \\
\hline Total & 72 & 100 \\
\hline
\end{tabular}

Tabel 4 di atas menunjukkan bahwa dari 72 responden yang dijadikan sampel, terdapat 4 responden $(5,6 \%)$ yang memiliki persepsi tentang kualitas pelayanan dari dimensi kepercayaan kurang dan terdapat 68 responden $(94,4 \%)$ yang memiliki persepsi tentang kualitas pelayanan dari dimensi kepercayaan cukup.

Tabel 5. Distribusi Persepsi Pasien Umum Kelas III Berdasarkan Citra Rumah Sakit Di RS. Ibnu Sina Makassar. $(n=72)$

\begin{tabular}{|c|c|c|}
\hline Citra RS & $\mathrm{n}$ & $\%$ \\
\hline Kurang Baik & 3 & 4,2 \\
\hline Baik & 69 & 95,8 \\
\hline Total & 72 & 100 \\
\hline
\end{tabular}


Tabel 5 di atas menunjukkan bahwa dari 72 responden yang dijadikan sampel, terdapat 3 responden $(4,2 \%)$ yang memiliki persepsi tentang citra rumah sakit ibnu sina kurang baik dan terdapat 69 responden $(95,8 \%)$ yang memiliki persepsi tentang citra rumah sakit ibnu sina baik.

2. Analisis Bivariat

Tabel 6. Hubungan Penampilan Fisik Terhadap Citra Rumah Sakit Di RS. Ibnu Sina Makassar. $(n=72)$

\begin{tabular}{|c|c|c|c|c|c|c|}
\hline $\begin{array}{c}\text { Penam } \\
\text { pilan } \\
\text { Fisik }\end{array}$ & Kurang & baik & $\begin{array}{c}\text { Citra } \\
\text { Rs }\end{array}$ & $\begin{array}{c}\text { Tota } \\
\text { I }\end{array}$ & \\
\hline & $\mathrm{n}$ & $\%$ & $\mathrm{n}$ & $\%$ & $\mathrm{n}$ & $\%$ \\
\hline Kurang & 0 & 0 & 2 & 2,9 & 2 & 2,8 \\
\hline Cukup & 3 & 100 & 67 & 97,1 & 70 & 97,2 \\
\hline TOTAL & 3 & 100 & 69 & 100 & 72 & 100 \\
\hline \multicolumn{7}{|c|}{ P Value $=1.000$} \\
\hline
\end{tabular}

Tabel 6 di atas menunjukkan bahwa dari 72 responden yang dijadikan sampel, terdapat 2 responden $(2,9 \%)$ yang memiliki persepsi tentang penampilan fisik kurang dengan citra rumah sakit yang baik. Sedangkan terdapat 3 responden (100\%) yang memiliki persepsi tentang dimensi penampilan fisik rumah sakit yang cukup dengan citra rumah sakit yang kurang baik.

Hasil uji statistik Chi Square diperoleh $p$ value sebesar 1,000 dengan ( $\alpha$ $=0,05$ ), maka dapat disimpulkan bahwa Ho diterima dan $\mathrm{Ha}$ ditolak, artinya bahwa tidak ada hubungan antara pengaruh persepsi pasien umum kelas III tentang kualitas pelayanan dari dimensi penampilan fisik terhadap citra rumah sakit di instalasi rawat inap rs ibnu sina.

Tabel 7. Hubungan Kompeten Terhadap Citra Rumah Sakit Di RS. Ibnu Sina Makassar. $(n=72)$

\begin{tabular}{|c|c|c|c|c|c|c|}
\hline $\begin{array}{c}\text { Kompete } \\
\mathrm{n}\end{array}$ & Citra & & $\mathrm{RS}$ & & \\
\hline & $\begin{array}{c}\text { Kurang } \\
\text { baik }\end{array}$ & & baik & & total & \\
\hline & $\mathrm{n}$ & $\%$ & $\mathrm{n}$ & $\%$ & $\mathrm{n}$ & $\%$ \\
\hline kurang & 2 & 66,7 & 3 & 4,3 & 5 & 6,5 \\
\hline cukup & 1 & 33,3 & 66 & 95,7 & 67 & 93,1 \\
\hline total & 3 & 100 & 69 & 100 & 72 & 100 \\
\hline \multicolumn{6}{|c}{ P Value $=0,011$} \\
\hline
\end{tabular}

Tabel 7 di atas menunjukkan bahwa dari 72 responden yang dijadikan sampel, masih terdapat $3(4,3 \%)$ pasien umum yang memiliki persepsi tentang kompeten kurang dengan citra rumah sakit yang baik dan terdapat 1 responden $(33,3 \%)$ yang memiliki persepsi tentang kompetensi yang cukup dengan citra rumah sakit yang kurang baik.

Hasil uji statistik Chi Square diperoleh $p$ value sebesar 0,000 dengan ( $\alpha$ $=0,05$ ), maka dapat disimpulkan bahwa $\mathrm{Ha}$ diterima dan Ho ditolak, artinya bahwa ada hubungan antara pengaruh persepsi pasien umum kelas III tentang kualitas pelayanan dari dimensi kompeten terhadap citra rumah sakit di instalasi rawat inap rs ibnu sina.

Tabel 8. Hubungan Kepercayaan Terhadap Citra Rumah Sakit Di RS. Ibnu Sina Makassar. $(n=72)$

\begin{tabular}{|c|c|c|c|c|c|c|c|}
\hline \multirow{3}{*}{$\begin{array}{l}\text { Keper } \\
\text { cayaan }\end{array}$} & \multicolumn{4}{|c|}{ Citra RS } & \multirow{2}{*}{\multicolumn{2}{|c|}{$\begin{array}{l}\text { To } \\
\text { tal }\end{array}$}} & \multirow{2}{*}{$\begin{array}{c}P \\
\text { Valu }\end{array}$} \\
\hline & \multicolumn{2}{|c|}{$\begin{array}{l}\text { Kuran } \\
\text { g baik }\end{array}$} & \multicolumn{2}{|c|}{ Baik } & & & \\
\hline & $n$ & $\%$ & $n$ & $\%$ & $\mathrm{n}$ & $\%$ & \\
\hline Kurang & 3 & 100 & 1 & $\overline{1,4}$ & 4 & 5,6 & 0,00 \\
\hline Cukup & 0 & 0 & 68 & $\begin{array}{c}98, \\
6\end{array}$ & 68 & $\begin{array}{c}94 \\
4\end{array}$ & \\
\hline Total & 3 & 100 & 69 & $\begin{array}{c}10 \\
0\end{array}$ & 72 & 100 & \\
\hline
\end{tabular}

Tabel 8 di atas menunjukkan bahwa dari 72 responden yang dijadikan sampel, terdapat 3 responden (100\%) yang memiliki persepsi tentang kepercayaan yang kurang dengan citra rumah sakit yang kurang baik, dan terdapat 1 responden $(1,4 \%)$ yang memiliki persepsi tentang kepercayaan kurang dengan citra rumah sakit yang baik.

Hasil uji statistik Chi Square diperoleh $p$ value sebesar 0,000 dengan ( $\alpha$ $=0,05$ ), maka dapat disimpulkan bahwa $\mathrm{Ha}$ diterima dan Ho ditolak, artinya bahwa ada hubungan antara pengaruh persepsi pasien umum kelas III tentang kualitas pelayanan dari dimensi kepercayaan terhadap citra rumah sakit di instalasi rawat inap rs ibnu sina.

\section{PEMBAHASAN}

Penampilan fisik dan aspek kebersihan pada penyedia jasa yang akan mendukung proses dalam memeberikan pelayanan kepada pasien yang terdiri dari atas fasilitas fisik, peralatan, personil dan komunikasi. Hasil uji statistik Chi Square disimpulkan bahwa Ho diterima dan $\mathrm{Ha}$ ditolak, artinya bahwa tidak ada hubungan antara pengaruh persepsi pasien umum tentang kualitas pelayanan dari dimensi penampilan fisik terhadap citra rumah sakit di instalasi rawat inap RS ibnu sina. Peneliti berasumsi bahwa kamar mandi yang ditempati pasien berbeda tingkat kebersihan, salah satu responden yang menjawab kurang, 
tentang ruangan, tempat tidur, makanan dan penampilan dokter dan perawatnya masih sangat jauh yang diharapkan, namun rumah sakit ibnu sina masih menjadi pilihan pasien untuk berobat dikarenakan, jarak dan kelengkapan alat serta obat yang dimiliki oleh rumah sakit ibnu sina, cukup bagus untuk pasien. Hal inilah menjadikan RS. Ibnu Sina menjadi pilihan dan memiliki citra bagus di masyarakat.

Kompeten merupakan suatu karakteristik yang mendasar dari seseorang individu, penyebab yang terkait dengan acuan kriteria tentang kinerja yang efektif karakteristik yang mendasari berarti kompetensi merupakan bagian dari kepribadian seseorang yang telah tertanam dan berlangsung lama dan dapat memprediksi perilaku dalam berbagai tugas dan situasi kerja. Berdasarkan hasil analisis chi square tentang pengaruh persepsi pasien umum tentang dimensi kompetensi petugas terhadap citra rumah sakit di instalasi rawat inap RS. Ibnu Sina dapat diketahui bahwa memiliki pengaruh yang signifikan. disimpulkan bahwa Ha diterima dan Ho ditolak, artinya bahwa ada hubungan antara pengaruh persepsi pasien umum tentang kualitas pelayanan dari dimensi kompeten terhadap citra rumah sakit di instalasi rawat inap RS ibnu sina.

Peneliti berasumsi bahwa kompetensi tenaga kesehatan utumanya dokter dan perawat yang secara langsung bersentuhan dengan pasien memiliki peran yang cukup kuat dalam meningkatkan kualitas pelayanan dan citra rumah sakit, oleh sebab itu perlu adanya kebijakan baru di setiap rumah sakit utamanya di RS. Ibnu Sina Makassar dalam meningkatkan kompetesi tenaga dokter dan perawat dalam mengobati dan merawat pasien, utamanya meningkatkan kolaborasi dalam mencegah dan menyembuhkan pasien. Hal ini sejalan dengan penelitian yang dilakukan oleh Faigah A Badjamal (2014) tentang pengaruh kompetensi terhadap kepuasan dan citra perusahaan, yang memiliki 8 point pertanyaan dikoesioner dengan hasil analisis bahwa kompetensi tenaga medis memiliki pengaruh yang signifikan terhadap kepuasan dan citra perusahaan dikemukakan.
Kepercayaan merupakan sifat jujur dan dapat dipercaya. Kredibilitas mencakup nama organisasi pelayanan kesehatan, reputasi, karakteristik pribadi contact personnel, dan interaksi dengan pelanggan Indikatornya adalah kepercayaan akan kehandalan rumah sakit ,kepercayaan konsumen untuk sembuh jika berobat ke rumah sakit, kepercayaan terhadap kualitas peralatan yang dimiliki rumah sakit, kepercayaan terhadap pelayanan rumah sakit yang diberikan/melakukan sesuai janji yang diberikan. Hasil uji statistik Chi Square disimpulkan bahwa Ha diterima dan Ho ditolak, artinya bahwa ada hubungan antara pengaruh persepsi pasien umum tentang kualitas pelayanan dari dimensi kepercayaan terhadap citra rumah sakit di instalasi rawat inap rs ibnu sina. Peneliti berasumsi bahwa tingkat kepercayaan pasien umum terhadap rumah sakit ibnu sina sangat tinggi, pasien percaya semua tindakan perawat dan dokter adalah demi kesembuhan pasien.

\section{KESIMPULAN}

1. Tidak ada hubungan antara pengaruh persepsi pasien umum kelas III tentang penampilan fisik keamanan terhadap citra rumah sakit di instalasi rawat inap rs ibnu dengan $(\alpha=0,05)$

2. Ada hubungan antara pengaruh persepsi pasien umum kelas III tentang kompeten dan kepercayaan terhadap citra rumah sakit di instalasi rawat inap rs ibnu sina dengan nilai $p$ value sebesar 0,000 dengan $(\alpha=0,05)$

\section{SARAN}

1. Pembenahan kualitas pelayanan dari dimensi untuk peningkatan citra rumah sakit harus dari prioritas perbaikan dimensi yang memiliki pengaruh yang kuat dalam peningkatan citra rumah sakit.

2. Penilaian citra rutin dilakukan secara berkala oleh pihak manajemen untuk menilai perkembangan sekaligus evaluasi citra rumah sakit

\section{DAFTAR PUSTAKA}

Badjamal Faigah A. 2014. Pengaruh Kualitas Pelayanan Terhadap Citra Perusahaan; Studi Kasus Rumah Sakit Islam Ibnu Sina. Pekanbaru

Sutker dalam cahyono, 2008. The Kaiser Family Foundation

WHO, 2017. Valentino, J, 2018. Pengaruh Pelayanan Prima (Services Axcellence) Terhadap Kepuasan Pelanggan Di Prima Swalayan Cabang Nganjuk. Skripsi. Malang : Universitas Brawijaya 